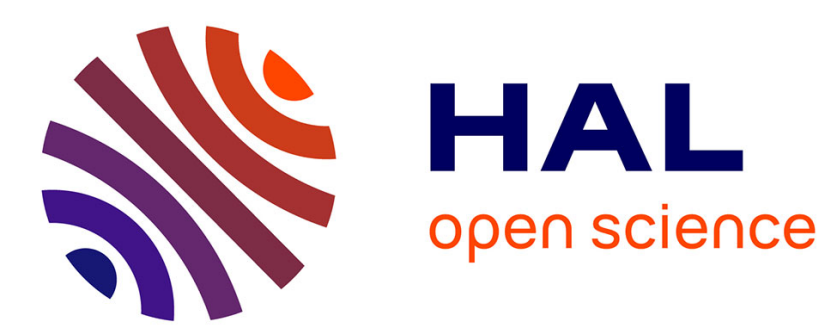

\title{
The Effects of Friction on the Compressive Behaviour of High Strength Steels
}

\author{
M. Ashton, D. Parry
}

\section{To cite this version:}

M. Ashton, D. Parry. The Effects of Friction on the Compressive Behaviour of High Strength Steels. Journal de Physique IV Proceedings, 1997, 07 (C3), pp.C3-271-C3-276. 10.1051/jp4:1997348 jpa00255505

\section{HAL Id: jpa-00255505 https://hal.science/jpa-00255505}

Submitted on 1 Jan 1997

HAL is a multi-disciplinary open access archive for the deposit and dissemination of scientific research documents, whether they are published or not. The documents may come from teaching and research institutions in France or abroad, or from public or private research centers.
L'archive ouverte pluridisciplinaire HAL, est destinée au dépôt et à la diffusion de documents scientifiques de niveau recherche, publiés ou non, émanant des établissements d'enseignement et de recherche français ou étrangers, des laboratoires publics ou privés. 


\title{
The Effects of Friction on the Compressive Behaviour of High Strength Steels
}

\author{
M. Ashton and D.J. Parry \\ Department of Physics, Loughborough University, Loughborough, Leicestershire LE11 3TU, U.K.
}

\begin{abstract}
An investigation, covering a wide range of strain rate and temperature. has been performed into the effects of interfacial friction on the compressive properties of an amour plate steel. In order to calculate the coefficient of friction, ring tests were carried out and the Avitzur analysis applied. In general. coefficients of friction decreased with increasing temperature and strain rate. Other specimen observations indicated the same friction trends. It is essential that friction corrections be applied if meaningful resuits are to be obtained.
\end{abstract}

Résumé : Une étude qui traite une sélection de vitesses de déformation et de températures est réalisée afin de connâtre les effets d'un frottement interfacial sur le comportement sous pression d'une plaque d'acier à blindage. Des calculs d'anneaux sont effectués et l'analyse d'Avitzur appliquée afin de calculer la coefficient de frottement. En général, les coefíicients de frottement baissent à une température et à une vilesse de déformation pius élevées. Plusieurs autres observations indiquent la mème tendance du frottement. Il est essentiel que les corrections du frottement soient appliquées afin d'obtenir des résultats significatifs.

\section{INTRODUCTION}

The accuracy of results obtained from the Split Hopkinson Pressure Bar (SHPB) depends on many interrelated factors including friction at the specimen faces. specimen inertia. specimen size. and wave propagation / dispersion effects [1-2]. To correct for all of these factors is often unnecessury. especially when a particular correction may only affect the final flow stress levels by a fraction of a percent. For example, lubricating many polymer specimens with petroleum gel reduces the friction at the specimen faces to a negligible amount [3]. However. friction at the specimen faces can vary greatly depending on the lubricant chosen and the material tested. Using ring specimens to assess the interfacial friction conditions between loading platens and a metal billet is a well-used technique in the metal forming industry. This technique is also used in the drop-weight method for high strain rate testing [4]. The use of the ring specimen with the SHPB test is very rare, even though it will allow the experimenter to investigate frictional effects over a high strain rate range at different temperatures. Lichtenberger et al. [5] have studied copper and $0.45 \%$ carbon steel ring specimens at room temperature using an SHPB and found, with suitable lubrication, that friction coefficients were relatively small and increased with strain rate. This paper uses Avitzur [6] ring theory to calculate friction corrections for Armour Plate steel tested at different strain rates and temperatures using an SHPB and a Hounsfield H50KM testing machine.

\section{AVITZUR THEORY}

When a hollow disk is compressed between rigid. parallel platens its outer radius increases. The inner radius might increase or decrease depending on the friction conditions prevalent. Avitzur has analysed the deformation of a ring specimen assuming the ring material obeys Mises" stress - strain rate laws. and that there is a constant shear factor between the disk and the platen fitces. 
For a ring specimen Avitzur derived the following two equations:

$$
\frac{P_{\text {ive }}}{\sigma_{o}}=\frac{1}{1-\left(\frac{R_{i}}{R_{0}}\right)^{2}}\left\{\sqrt{1+\frac{1}{3}\left(\frac{R_{n}}{R_{0}}\right)^{4}}-\sqrt{\left(\frac{R_{i}}{R_{0}}\right)^{4}+\frac{1}{3}\left(\frac{R_{n}}{R_{0}}\right)^{4}}+\frac{2}{3 \sqrt{3}} m \frac{R_{0}}{T}\left[1-\left(\frac{R_{i}}{R_{o}}\right)^{3}\right]\right\}
$$

for $R_{n} \leq R_{i}$, and:

$$
\frac{P_{\text {ave }}}{\sigma_{0}}=\frac{1}{1-\left(\frac{R_{i}}{R_{0}}\right)^{2}}\left\{\sqrt{1+\frac{1}{3}\left(\frac{R_{n}}{R_{o}}\right)^{4}}-\sqrt{\left(\frac{R_{i}}{R_{0}}\right)^{4}+\frac{1}{3}\left(\frac{R_{n}}{R_{0}}\right)^{4}}+\frac{2}{3 \sqrt{3}} m \frac{R_{o}}{T}\left[1+\left(\frac{R_{i}}{R_{o}}\right)^{3}-2\left(\frac{R_{n}}{R_{o}}\right)^{3}\right]\right\}
$$

for $R_{i} \leq R_{n}<R_{0}$.

Where: $P_{\text {ave }}$ is the average normal stress applied, $\sigma_{0}$ the effective flow stress, $R_{i}$ the internal radius. $R_{0}$ the outer radius, $R_{n}$ the neutral radius, $m$ the constant shear factor, $T$ the thickness.

The average Coulomb coefficient of friction $\mu_{\text {ave }}$ (or simply $\mu$ ) is related to the shear stress $\tau$, and hence $\mathrm{m}$, by:

$$
\mu=\mu_{\mathrm{ave}}=\frac{\tau}{\mathrm{P}_{\mathrm{ave}}}=\frac{\mathrm{m} \sigma_{0} / \sqrt{3}}{\mathrm{P}_{\mathrm{ave}}}=\frac{\mathrm{m} / \sqrt{3}}{\mathrm{P}_{\mathrm{ave}} / \sigma_{\mathrm{o}}}
$$

Equations 1 and 2 are used to calculate how $\mathrm{P}_{\mathrm{ave}} / \sigma_{\mathrm{o}}$ varies with strain. Then from equation 3 it is possible to find the variation of the coefficient of friction with strain, if $m$ is known.

For any given ring test, the relevant specimen details and a range of values for $\mathrm{m}$ are processed by a Qbasic program. For each value of $\mathrm{m}$, a different set of final specimen inner and outer diameter dimensions are obtained from the program. The final inner and outer diameter dimensions predicted by the program are matched with the real final specimen dimensions, and hence a value for $\mathrm{m}$ is determined. Friction corrections are applied to solid specimens by using the constant shear factor from the equivalent ring test and applying the above equations, substituting $R_{i}=R_{n}=0$ in equation 1 or 2 . The value of $P_{\text {ilve }} / \sigma_{0}$ is not constant throughout a test. However, since it changes by $< \pm 1 \%$ for quasistatic or dynamic tests, average values are quoted in this paper.

\section{EXPERIMENTAL}

Two armour plate steels have been used to conduct the work in this paper: ARP and RHA/UK100. Both steels have a room temperature quasistatic yield stress of about $900 \mathrm{MPa}$. A small quantity of ARP specimens was initially supplied, and have been used only in part of the preliminary work of selecting the most suitable lubricant. All the friction corrections calculated / applied in this paper are based on RHA/UK 100 tests.

Specimen faces of ARP and RHA/UK 100 have been examined using a Burleigh Personal SPM atomic lorce microscope in contact mode. Figure 1 shows typical surface topography for ARP and RHA/UK 100 specimens. The ARP specimens have a turned and then honed surface finish which at this magnification appears quite random with an average roughness of about $70 \mathrm{~nm}$. The RHA/UK 100 specimens have a fine ground surface finish with an average roughness of about $120 \mathrm{~mm}$. To see if this difference in surface roughness between the two steels would affect the interfacial friction, some of the ARP specimens were ground to an average roughness of about $120 \mathrm{~nm}$. Tests on ARP specimens with these two different surface roughness values gave the same results, and hence the difference in surface roughness between any of the specimens in this report has no effect on interfacial friction variations.

High strain rate ests were carried out with a $12.7 \mathrm{~mm}$ diameter modified SHPB system 17). This modilied sysem uses a pre-loading bar in front of the conventional system to smooth the loading pulse 
resulting in much smaller oscillations on the final stress-strain curve than in conventional systems. A copper cooling jacket filled with liquid nitrogen was placed around the specimen and part of the loading bars for tests below room temperature. The specimen temperature was monitored with a K-type thermocouple soldered onto the side of the specimen. An initial comparison of stress-strain curves for specimens with and without thermocouples attached, proved that the attachment of the thermocouple did not affect the deformation process in any way.

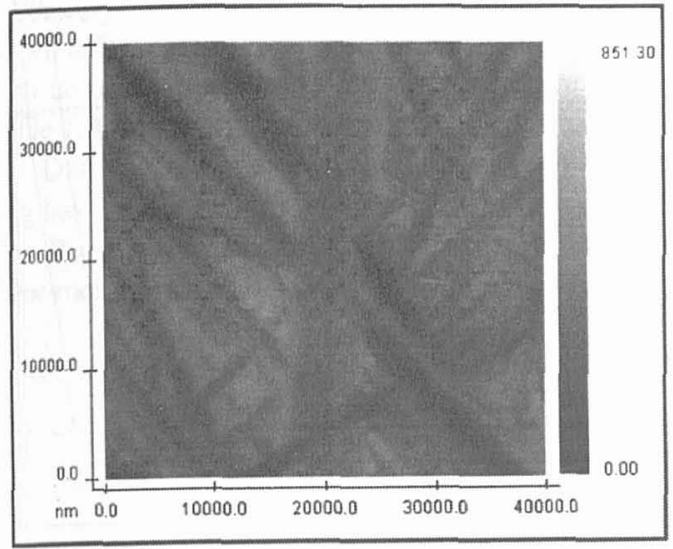

a)

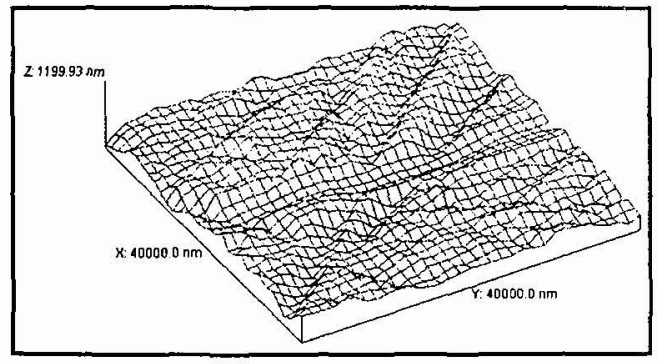

b)

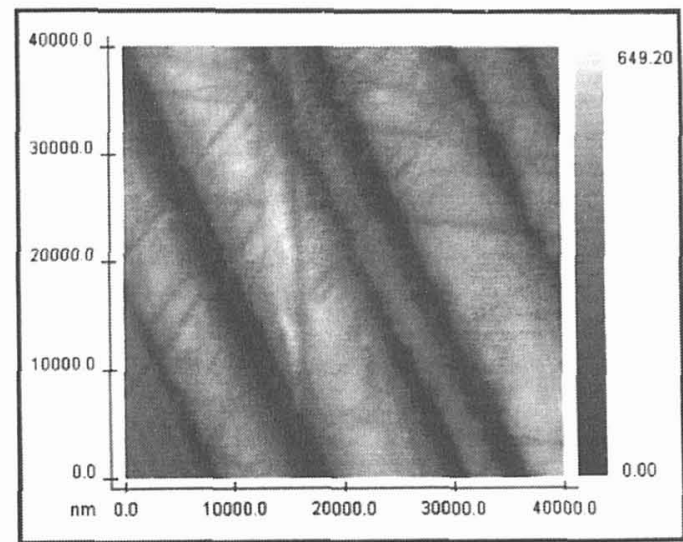

c)

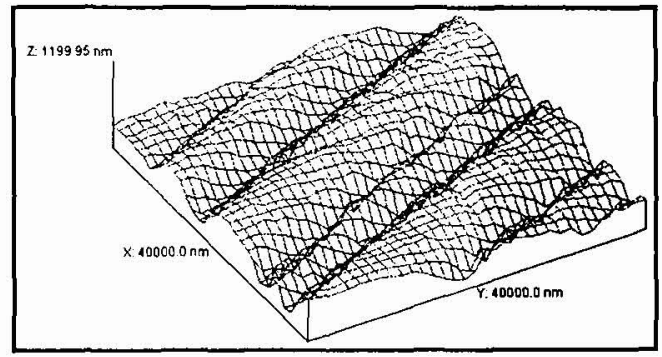

d)

Figure 1: Atomic force micrographs and three-dimensional profile maps: a) and b) ARP steel; c) and d) RHAJK100 steel.

A range of lubricants was initially tested at $20^{\circ} \mathrm{C}$ and about $1000 \mathrm{~s}^{-1}$ using ARP armour plate solid disc specimens of $8 \mathrm{~mm}$ diameter by $4 \mathrm{~mm}$ length (Figure 2a). The lubricant giving the lowest value for the specimen flow stress was adjudged to have the lowest friction. The lubricant order from highest to lowest friction is given in the Figure 2a legend. Although PTFE spray produced the lowest friction, the vacuum grease was chosen as best overall because it was easier to apply consistently and gave a measured yield stress only $30 \mathrm{MPa}$ higher than the PTFE spray.

Another set of lubricants was tested at $-100^{\circ} \mathrm{C}$ and about $700 \mathrm{~s}^{-1}$ (Figure 2b). The flow stress curves obtained with these lubricants overlapped within experimental error $( \pm 2 \%)$ indicating little difference in their lubricating properties, and hence vacuum grease was chosen for all the further dynamic tests in this work.

Quasistatic investigations were performed with a $50 \mathrm{kN}$ screw driven Hounsfield H50KM testing machine. The vacuum grease was also chosen as the lubricant for all quasistatic tests so comparisons could be drawn with the dynamic tests. Quasistatic tests at $-40{ }^{\circ} \mathrm{C}$ used an insulated copper cooling jacket filled with liquid nitrogen. Pilkington $\mathrm{K}$-lype glass anvils were used between the main machine platens and smaller platens adjacent to the specimen. Both the small platens adjacent to the specimen and the 
specimen had K-type thermocouples soldered on to them to monitor the temperature, and check that there was not a thermal gradient across the specimen. Unfortunately, it was not possible to cool the specimen to $-100{ }^{\circ} \mathrm{C}$ without severe thermal gradients across the specimen.

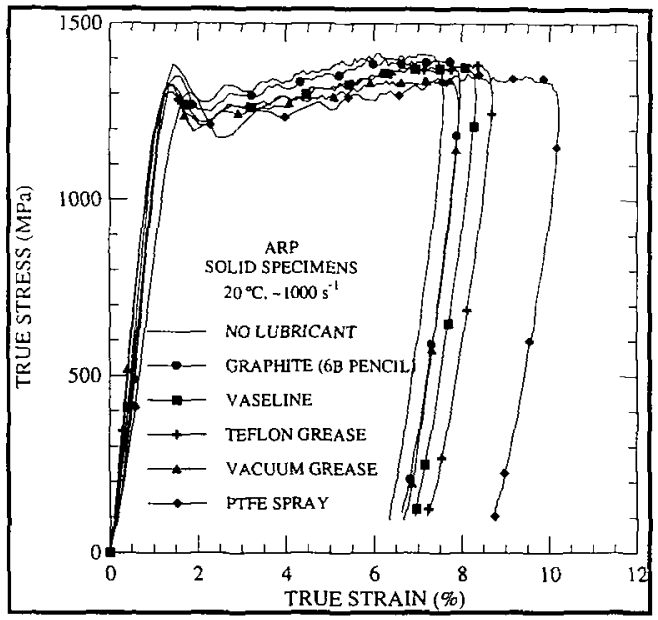

a)

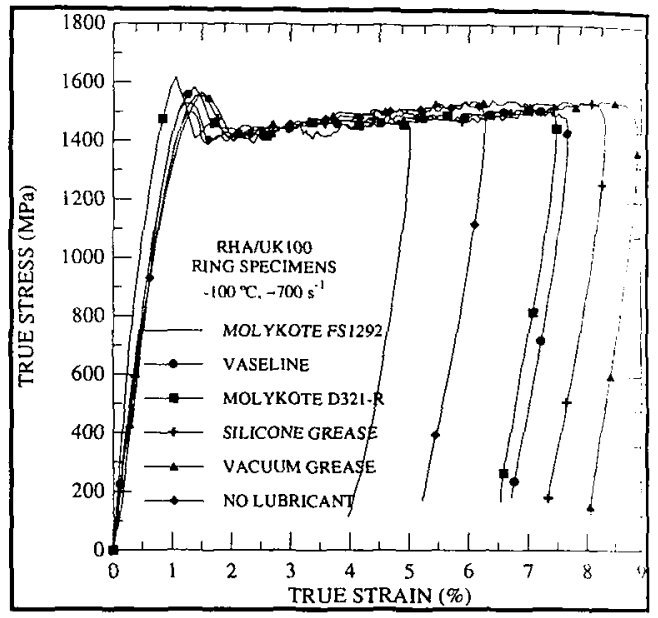

b)

Figure 2: Selection of lubricants at: a) $20^{\circ} \mathrm{C}$; b) $-100^{\circ} \mathrm{C}$.

Table 1: Macroscopic Data Results.

\begin{tabular}{|c|c|c|c|c|c|c|c|c|c|c|c|}
\hline & & & $\begin{array}{c}\mathrm{MRW}_{\mathrm{AVE}} \\
(\mathrm{mm})\end{array}$ & $\begin{array}{c}\mathrm{MRW}_{\mathrm{PRED}} \\
(\mathrm{mm})\end{array}$ & $\begin{array}{l}\mathrm{MRW}_{\mathrm{AVE}} / \\
\mathrm{MRW}_{\mathrm{PRED}}\end{array}$ & No. $\mathrm{R}_{\mathrm{MIN}}$ & $\begin{array}{c}\rho \\
(\mathrm{cm})\end{array}$ & $m$ & $\mu$ & $P_{\mathrm{ave}} / \sigma_{0}$ & $\begin{array}{c}\mathrm{d} \\
(\mathrm{mm}) \\
\end{array}$ \\
\hline \multirow[t]{6}{*}{$20^{\circ} \mathrm{C}$} & \multirow[t]{3}{*}{ SOLID } & QUASISTATIC & $\begin{array}{l}0.10 \\
0.09\end{array}$ & $\begin{array}{l}0.125 \\
0.177\end{array}$ & $\begin{array}{l}0.80 \\
0.51\end{array}$ & $\begin{array}{l}1 \\
1\end{array}$ & $\begin{array}{l}>3.3,>3.3 \\
>3.3,>3.3\end{array}$ & $\begin{array}{l}0.35 \\
0.35\end{array}$ & $\begin{array}{c}0.18 \\
0.18 \mathrm{NL}\end{array}$ & $\begin{array}{l}1.12 \\
1.13\end{array}$ & $\begin{array}{l}6.9 \\
6.9\end{array}$ \\
\hline & & $\approx 1000 \mathrm{~s}^{-1}$ & $\begin{array}{l}0.15 \\
0.13\end{array}$ & $\begin{array}{l}0.204 \\
0.183\end{array}$ & $\begin{array}{l}0.74 \\
0.71\end{array}$ & $\begin{array}{l}10 \\
8\end{array}$ & $\begin{array}{l}>3.3,>3.3 \\
>3.3,>3.3\end{array}$ & $\begin{array}{l}0.18 \\
0.18\end{array}$ & $\begin{array}{l}0.10 \\
0.10 \\
\end{array}$ & $\begin{array}{l}1.08 \\
1.07 \\
\end{array}$ & $\begin{array}{l}8.0 \\
6.9 \\
\end{array}$ \\
\hline & & $\Rightarrow 2000 \mathrm{~s}^{-1}$ & 0.23 & 0.433 & 0.53 & 15 & $2.1,2.2$ & 0.17 & 0.09 & 1.07 & 6.9 \\
\hline & \multirow[t]{3}{*}{ RING } & QUASISTATIC & $\begin{array}{l}0.09 \\
0.10\end{array}$ & $\begin{array}{l}0.128 \\
0.129 \\
\end{array}$ & $\begin{array}{l}0.70 \\
0.78 \\
\end{array}$ & $\begin{array}{l}1 \\
1\end{array}$ & $\begin{array}{l}2.5,2.5 \\
2.3,2.8\end{array}$ & $\begin{array}{l}0.35 \\
0.35\end{array}$ & $\begin{array}{c}0.18 \\
0.18 \mathrm{NL}\end{array}$ & $\begin{array}{l}1.14 \\
1.14\end{array}$ & $\begin{array}{l}8.0 \\
8.0 \\
\end{array}$ \\
\hline & & $\approx 1000 \mathrm{~s}^{-1}$ & 0.12 & 0.164 & 0.73 & 7 & $>3.3,>3.3$ & 0.18 & 0.10 & 1.08 & 8.0 \\
\hline & & $\approx 2000 \mathrm{~s}^{-1}$ & 0.25 & 0.427 & 0.59 & 14 & $2.0,<3.3$ & 0.17 & 0.09 & 1.08 & 8.0 \\
\hline \multirow[t]{6}{*}{$-40^{\circ} \mathrm{C}$} & \multirow[t]{3}{*}{ SOLID } & QUASISTATIC & $\begin{array}{l}0.07 \\
0.07\end{array}$ & $\begin{array}{l}0.094 \\
0.078\end{array}$ & $\begin{array}{l}0.74 \\
0.90\end{array}$ & $\begin{array}{l}1 \\
1\end{array}$ & $\begin{array}{l}>3.3,>3.3 \\
>3.3,>3.3\end{array}$ & $\begin{array}{l}0.35 \\
0.40\end{array}$ & $\begin{array}{c}0.18 \\
0.20 \mathrm{NL}\end{array}$ & $\begin{array}{l}1.12 \\
1.14\end{array}$ & $\begin{array}{l}6.9 \\
6.9 \\
\end{array}$ \\
\hline & & $\approx 1000 \mathrm{~s}^{-1}$ & $\begin{array}{l}0.12 \\
0.12\end{array}$ & $\begin{array}{l}0.142 \\
0.216\end{array}$ & $\begin{array}{l}0.85 \\
0.56\end{array}$ & $\begin{array}{l}6 \\
6\end{array}$ & $\begin{array}{l}>3.3,3.3 \\
2.3,>3.3\end{array}$ & $\begin{array}{l}0.35 \\
0.35\end{array}$ & $\begin{array}{l}0.18 \\
0.18\end{array}$ & $\begin{array}{l}1.14 \\
1.13\end{array}$ & $\begin{array}{l}8.0 \\
6.9\end{array}$ \\
\hline & & $\approx 2000 \mathrm{~s}^{-1}$ & 0.16 & 0.316 & 0.51 & 8 & 1.6 .3 .3 & 0.15 & 0.08 & 1,06 & 6.9 \\
\hline & \multirow[t]{3}{*}{ RING } & QUASISTATIC & $\begin{array}{l}0.06 \\
0.03\end{array}$ & $\begin{array}{l}0.064 \\
0.085\end{array}$ & $\begin{array}{l}0.94 \\
0.35\end{array}$ & $\begin{array}{l}1 \\
1\end{array}$ & $\begin{array}{c}>3.3,>3.3 \\
3.0,3.0\end{array}$ & $\begin{array}{l}0.35 \\
0.40\end{array}$ & $\begin{array}{c}0.18 \\
0.20 \mathrm{NL}\end{array}$ & $\begin{array}{l}1.13 \\
1.15\end{array}$ & $\begin{array}{l}8.0 \\
8.0 \\
\end{array}$ \\
\hline & & $\approx 1000 \mathrm{~s}^{-1}$ & 0.08 & 0.106 & 0.75 & 2 & $>3.3 .3 .3$ & 0.35 & 0.18 & 1.14 & 8.0 \\
\hline & & $\approx 2000 \mathrm{~s}^{-1}$ & 0.11 & 0.317 & 0.35 & 2 & $>3.3,<3.3$ & 0.15 & 0.08 & 1.07 & 8.0 \\
\hline \multirow[t]{4}{*}{$-100^{\circ} \mathrm{C}$} & \multirow[t]{2}{*}{ SOLID } & $\approx 1000 \mathrm{~s}^{-1}$ & 0.11 & 0.145 & 0.76 & 3 & $3.3,>3.3$ & 0.30 & 0.16 & 1.11 & 6.9 \\
\hline & & $\approx 2000 \mathrm{~s}^{-1}$ & 0.15 & 0.308 & 0.49 & 8 & $1.8,>3.3$ & 0.25 & 0.13 & 1.10 & 6.9 \\
\hline & \multirow[t]{2}{*}{ RING } & $\approx 1000 \mathrm{~s}^{-1}$ & 0.09 & 0.088 & "1.00" & 2 & $3.3,2.5$ & 0.30 & 0.15 & 1.12 & 8.0 \\
\hline & & $=2000 \mathrm{~s}^{-1}$ & 0.16 & 0.277 & 0.58 & 4 & $2.5, \overline{1.4}$ & 0.25 & 0.13 & 1.11 & 8.0 \\
\hline
\end{tabular}

Tests were performed at $20^{\circ} \mathrm{C},-40^{\circ} \mathrm{C}$ and $-100^{\circ} \mathrm{C}$ over a strain rate range of approximately $10^{-3}$. $2 \times 10^{3} \mathrm{~s}^{-1}$ (Figure 3). At least two tests were performed under each set of conditions, more if the tcsts dit not agree within experimental error $( \pm 2 \%)$. Table 1 shows information for $6.9 \mathrm{~mm}$ and $8.0 \mathrm{~mm}$ vuler 
diameter (d) by $4.0 \mathrm{~mm}$ length solid specimens, and $8.0 \mathrm{~mm}$ outer diameter by $4.0 \mathrm{~mm}$ inner diameter by $4.0 \mathrm{~mm}$ length ring specimens. $6.9 \mathrm{~mm}$ diameter specimens can be tested to greater strains. Specimens tested without a lubricant are labelled NL in Table 1.

The barrelling of the specimens was measured by first photographing the specimens using fine grain Ilford Pan F Plus film with lighting to enhance the edge contrast, and then enlarging (total magnification $x 60$ ) and tracing the negative image on a microfiche reader. Figure 4 shows the specimen tested at $20^{\circ} \mathrm{C}$, $2790 \mathrm{~s}^{-1}$ to a strain of $25 \%$. The barrelling radius of curvature $\rho$ was measured by overlapping a set of predrawn arcs over the traced images. Pre-drawn arcs with radii greater than $200 \mathrm{~cm}$ were difficult to produce with accuracy and hence radii of curvature greater than $3.3 \mathrm{~cm}(200 / 60 \mathrm{~cm})$ are quoted as $>3.3 \mathrm{~cm}$ in Table 1. Radii of curvature quoted as $<3.3 \mathrm{~cm}$ in Table 1 are less than $3.3 \mathrm{~cm}$ but not perfect arcs.

During testing a ring (the "major ring") forms around the edges of the specimen faces. This major ring has "minor rings" within it. The width of the major ring $\left(\mathrm{MRW}_{\mathrm{AVE}}\right)$, and the number of minor rings (No. $R_{\text {MIN }}$ ) were measured with a travelling microscope with a resolution of $0.01 \mathrm{~mm}$ (Figure $4 \mathrm{~b}$ ). Each of these measurements as given in Table 1 was an average of eight readings per specimen.

\section{RESULTS AND DISCUSSION}

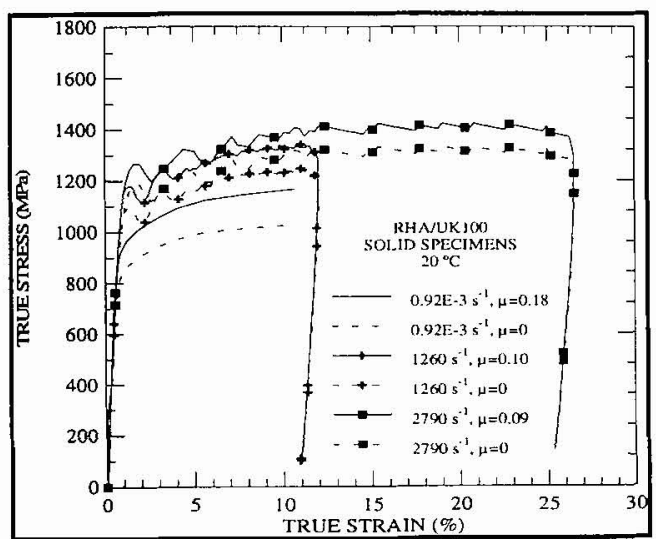

3a)

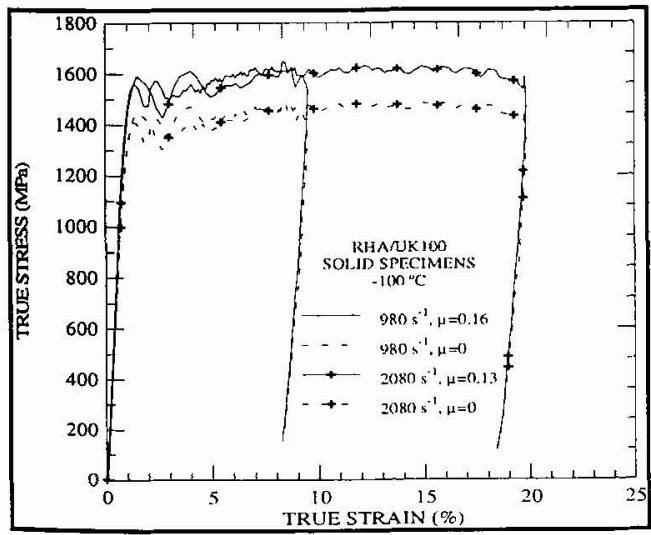

3c)

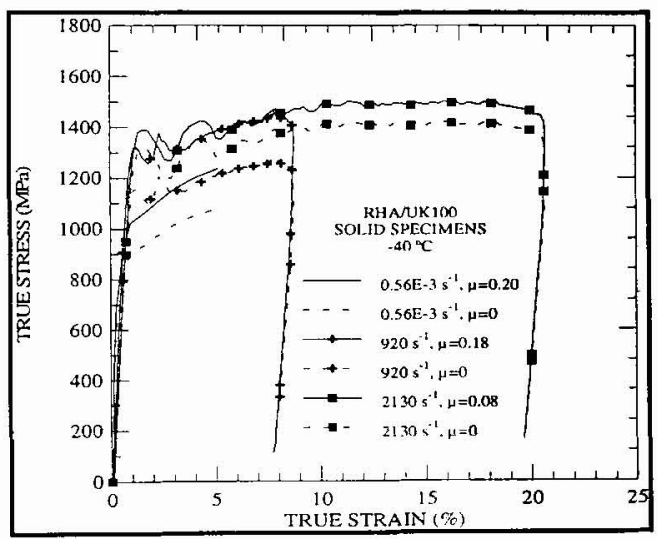

3b)

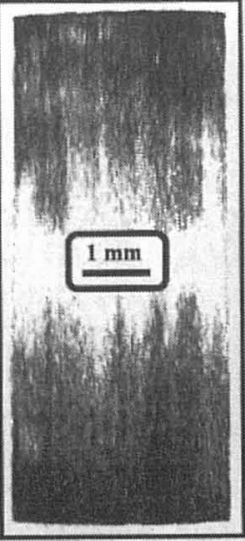

4a)

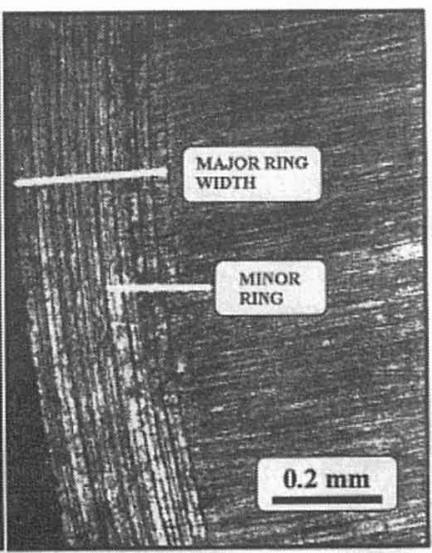

4b)
Figure 3: RHA/UK 100 results at: a) $20{ }^{\circ} \mathrm{C}:$ b) $\left.-40{ }^{\circ} \mathrm{C}: \mathrm{c}\right)-100^{\circ} \mathrm{C}$

Figure 4: Typical specimen: a) harrelling: b) face. 
The stress-strain curves for RHA/UK100 solid specimens are shown in Figure 3. Those labelled $\mu=0$ have been corrected for friction. RHA/UK100 ring specimen stress-strain curves are not shown as the! overlap the solid specimen curves within experimental error $( \pm 2 \%)$. RHA/UK100 is not strain rate sensitive below room temperature over the strain rate range of about 1000-2000 $\mathrm{s}^{-1}$. Thermal softening caln be seen in many of the flow stress curves.

In quasistatic tests at $20^{\circ} \mathrm{C}$ and $-40^{\circ} \mathrm{C}, \mu$ was about 0.18 and the flow stress reduction to correct for friction was about $14 \%$. Probably as a consequence of the high stress levels, the specimen and platen faces at the end of a test showed virtually all the lubricant was squeezed out; indeed quasistatic flow stress levels for lubricated or unlubricated specimens were identical (not shown in Figure 3).

In dynamic tests the friction decreased with increasing strain rate, in agreement with results found by Lichtenberger et al. [5]. As the temperature decreased from $20^{\circ} \mathrm{C}$ to $-40^{\circ} \mathrm{C}$ the friction also increased for a given strain rate. The coefficient of friction values at $-100^{\circ} \mathrm{C}$ are similar to the $-40^{\circ} \mathrm{C}$ values.

The predicted major ring width (MRW $W_{\text {PRED }}$ ) was calculated as half the difference between the specimen's initial and final outer diameters. MRW PRED is therefore the major ring width assuming the edges of the specimen interlock with the loading faces at the beginning of the test; this occurs whin friction is very high. $\mathrm{MRW}_{\mathrm{AVE}} / \mathrm{MRW}_{\mathrm{PRED}}$ in Table 1 is a rough guide to the level of interfacial friction taking into account the difference in specimen diameter when necessary. In general, this ratio decreases with increasing strain rate, again an indication of friction decreasing with increasing strain rate. The minor rings inside the major ring are probably due to the edge of the specimen sticking and sliding as the material folds around from the sides to the faces of the specimen. The number of minor rings is probably it function of strain, strain rate and friction, but it is interesting to note that more rings appear in dynamic tests with lower rather than higher friction at a given strain rate. Whereas the major ring width is a good indicator of friction, the barrelling radius of curvature appears to be more a function of strain than friction.

SHPB simulations using DYNA2D have been run to model the room temperature dynamic tests. Very good agreement is found between the simulations and the actual tests. For example, the difference in flow stress for a simulation of the $2790 \mathrm{~s}^{-1}$ test in Figure 3a for zero friction and $\mu=0.1$ is $100 \mathrm{MPa}$. exactly the same correction predicted by Avitzur theory.

\section{CONCLUSIONS}

Measured flow stress levels for high strength materials depend greatly on lubricant performance. The major ring width is a much better indicator of friction than the barrelling radius of curvature. In generul. friction appears to decrease with increasing strain rate and temperature for RHA/UK100 steel lubricated with vacuum grease.

\section{Acknowledgements}

One of the authors (MA) was supported by DRA Fort Halstead (Mr. B. D. Goldthorpe), who also kindly provided the materials for this investigation and computing facilities for the finite element work.

\section{References}

[1] Gorham, D. A., Pope, P. H., Cox, O., "Sources of error in very high strain rate compression tests", 3rd Conf. on Mechanical Properties at High Rates of Strain, Oxford 1984, J. Harding Ed. (I.O.P., Bristol, 1984), pp. 151-158.

[2] Gorham, D. A., Pope, P. H., Field, J. E., Proc. R. Soc. A 438 (1992) 153-170.

[3] Briscoe, B. J., Nosker, R. W., Wear, 95 (1984) 241-262.

[4] Male, A. T., Cockcroft, M. G., Journal of the Institute of Metals, 93 (1964) 38-46.

[5] Lichtenberger, A., Lach, E., Bohmann, A., C8, J. de Physique III, 4 (1994) 29-34.

16| Avitzur, B.. Israel Journal of Technology, 2 No. 3 (1964) 295-304.

[7] Parry, D. J., Walker, A. G., Dixon, P. R.. Meas. Sci. Technol. 6 (1995) 443-446. 